\section{The Use of Biodegradable Mulches in Pie Pumpkin Crop Production in Two Diverse Climates}

\author{
Shuresh Ghimire ${ }^{1,6}$ \\ Department of Horticulture, Northwestern Washington Research and \\ Extension Center, Washington State University, 16650 State Route 536, \\ Mount Vernon, WA 98273
}

\author{
Annette L. Wszelaki ${ }^{2}$ and Jenny C. Moore ${ }^{3}$ \\ Department of Plant Sciences, University of Tennessee, 2431 Joe Johnson \\ Drive, Knoxville, TN 37996
}

Debra Ann Inglis ${ }^{4}$
Department of Plant Pathology, Northwestern Washington Research and
Extension Center, Washington State University, 16650 State Route 536,
Mount Vernon, WA 98273

Carol Miles 5

Department of Horticulture, Northwestern Washington Research and Extension Center, Washington State University, 16650 State Route 536, Mount Vernon, WA 98273

Additional index words. biodegradable plastic mulch, paper mulch, soil exposure, crop yield, crop quality, mulch adhesion

\begin{abstract}
The use of plastic biodegradable mulch (BDM) in many vegetable crops such as tomato (Solanum lycopersicum L.), broccoli (Brassica oleracea L. var. italica), and pepper (Capsicum annuum L.) has been proven to be of equal benefit as polyethylene (PE) mulch. However, there are limited research findings on the performance of BDM with a large fruited crop such as pumpkin (Cucurbita pepo $\mathrm{L}$.) where the fruit can rest directly on the mulch for an extended period. To investigate whether heavy fruit might cause the mulch to degrade more quickly than expected, thereby, influencing weed control, fruit yield, and fruit quality including mulch adhesion on fruit, we carried out a field experiment in 2015 and 2016 at two locations in the United States with distinctive climates, Mount Vernon, WA and Knoxville, TN. Three plastic mulches marketed as biodegradable (BioAgri, Organix, and Naturecycle), one fully biodegradable paper mulch (WeedGuardPlus), and one experimental plastic BDM consisting of polylactic acid and polyhydroxyalkanoates (Exp. PLA/PHA) were evaluated against PE mulch and bare ground where 'Cinnamon Girl' pie pumpkin was the test crop. There was significant weed pressure in the bare ground plots at both locations over both years, indicating viable weed seed banks at the field sites. Even so, weed pressure was minimal across mulch treatments at both locations over both years because the mulches remained sufficiently intact during the growing season. The exceptions were Naturecycle in 2015 at both locations because of the splitting of the mulch and consequently higher percent soil exposure (PSE), and the penetration of all the plastic mulches at Knoxville by nutsedge (Cyperus sp. L.); nutsedge did not penetrate WeedGuardPlus. At Mount Vernon, overall pumpkin yield across both years averaged $18.1 \mathrm{t}^{\mathrm{h} \mathrm{h}^{-1}}$, and pumpkin yield was the greatest with PE, Exp. PLA/ PHA, BioAgri, and Naturecycle (19.9-22.8 t. ha $\left.{ }^{-1}\right)$, intermediate with Organix and WeedGuardPlus (15.3-18.4 th $\left.\mathrm{ha}^{-1}\right)$, and the lowest for bare ground $\left(8.7 \mathrm{t} \cdot \mathrm{ha}^{-1}\right)$. At Knoxville, overall pumpkin yield across both years averaged $17.7 \mathrm{t} \cdot \mathrm{ha}^{-1}$, and pumpkin yield did not differ because of treatment $\left(15.3-20.4 \mathrm{t} \cdot \mathrm{ha}^{-1}\right)$. The differences in yield between treatments at Mount Vernon were likely because of differences in the soil temperature. At $10 \mathrm{~cm}$ depth, the average soil temperature was $1^{\circ} \mathrm{C}$ lower for bare ground and WeedGuardPlus as compared with PE mulch and plastic BDMs $\left(20.8^{\circ} \mathrm{C}\right)$. In contrast, soil temperatures were generally higher $\left(25.2\right.$ to $\left.28.3^{\circ} \mathrm{C}\right)$ for all treatments at Knoxville and more favorable to crop yield compared with Mount Vernon. Forty-two percent to 59\% of pumpkin fruit had mulch adhesion at harvest at Mount Vernon, whereas only $3 \%$ to $12 \%$ of fruit had mulch adhesion at Knoxville. This difference was because of the location of fruit set-at Mount Vernon, most of the fruit set was on the mulch whereas at Knoxville, vine growth was more extensive and fruit set was mostly in row alleys. Fruit quality differences among treatments were minimal during storage across both locations and years except for total soluble solids (TSS) in 2016, which was lower for bare ground and WeedGuardPlus compared with all the plastic mulches. Taken overall, these results indicate that pie pumpkin grown with BDM has fruit yield and quality comparable to PE mulch; however, adhesion of some BDMs on fruit could affect marketable yield. Furthermore, paper mulch appears to prevent nutsedge penetration.
\end{abstract}

Polyethylene mulch has been used in agriculture for more than 60 years and contributes to crop yield and quality by reducing weed pressure and herbicide use, moderating soil temperature, and conserving soil moisture (Emmert, 1957; Ibarra-Jimenez et al., 2006; Kasirajan and Ngouajio, 2012; Lamont, 2005). In 2011, PE mulch was applied on nearly 20 million ha in China with use projected to grow $7 \%$ or more annually (Liu et al., 2014). At nearly the same time, in 2012 , an estimated 89.2 thousand $t$ of PE mulch was used in North America, and the projected use is estimated to be $\approx 106$ thousand $t$ in 2017 (MarketsandMarkets, 2012).

Despite its many benefits, used PE mulch is difficult to recycle as it is contaminated with soil and/or vegetation (up to $50 \%$ by weight) (Kasirajan and Ngouajio, 2012). Currently, only $10 \%$ of agricultural plastics are recycled (Grossman, 2015; Levitan and Barros, 2003), mostly because not all facilities will accept used PE mulch because of the difficulty of removing adhering soil and plant debris (Levitan and Barros, 2003). PE mulch removal and disposal in a landfill is costly, up to $\$ 584 /$ ha (Galinato and Walters, 2012; Galinato et al., 2012). The lack of affordable recycling and disposal choices has left farmers with few end-of-life options for PE mulch at the end of the growing season. Thus, many farmers dispose used PE mulches in landfills, or stockpile it on-site, whereas others till it into the soil or burn it on-site (Kasirajan and Ngouajio, 2012).

Mulch that can be tilled into the soil after crop harvest and thereafter biodegrades in the soil may provide farmers with an environmentally beneficial and low-cost disposal option. Several BDM alternatives to PE mulch have been developed, including paper and plastic BDMs. Although paper mulch has been shown to fully biodegrade in soil (Haapala et al., 2014; Li et al., 2014), it tends to breakdown too rapidly during the growing season, especially along the sides of the bed where there is direct soil contact (Merfield, 2000; Miles et al., 2012). Also, brown paper mulch (WeedGuardPlus; Sunshine Paper Co., Aurora, CO) has been shown to lower soil temperature by 0.5 and $1{ }^{\circ} \mathrm{C}$ compared with bare ground in open field and high tunnel tomato production systems, respectively, resulting in lower yields compared with black PE mulch (Cowan et al., 2014). Plastic BDM has been reported to perform similarly to PE mulch with regard to soil temperature and yield. Studies in Spain (Anzalone et al., 2010; Martin-Closas et al., 2008) and the United States (Cowan et al., 2014) found that tomato yield is similar when plants are grown with black plastic and brown paper BDMs compared with black PE mulch in most years. In one study, the percentage of ripe fruit was lower for brown paper and black plastic BDMs compared with black PE mulch only in 1 year of a 3-year study (Anzalone et al., 2010). Waterer (2010) compared the field performance of black and clear BioTelo (consisting of Mater-Bi polymeric resin; Novamont, Novara, Italy) and 
black and clear PE mulch for the production of five warm season vegetable crops ['Navajo' sweet corn (Zea mays L.), 'Goldrush' zucchini (C. pepo), 'Fastbreak' muskmelon (Cucumis melo L. var. reticulatus), 'Redstart' pepper, and 'Dusky' eggplant (Solanum melongena L.)] over three cropping seasons in Saskatchewan, Canada. No significant differences in soil temperature, crop growth, or yield responses were found for the BDMs as compared with the same color of PE mulch, whereas mulch adhesion on fruit was not mentioned.

Weed control is the primary function of mulch; thus, a BDM must remain intact on the soil surface long enough to provide a barrier to weed seed germination and growth. The critical period of weed control for tomato is $4-5$ weeks after transplanting (Weaver and Tan, 1983). During this time, competition with weeds may decrease plant size and the number of marketable fruit. PE mulch and two plastic BDMs (both Mater-Bi based) gave similar weed suppression throughout the tomato production season, despite $15 \%$ of the bed becoming exposed because of mulch deterioration for BDMs (Minuto et al., 2008). Cowan et al. (2014) likewise found that tomato yield was not reduced by weed growth that occurred when soil was exposed over the course of the growing season because of mulch deterioration. Pumpkin has a relatively long growing season, and the critical period for weed control has been estimated to last until 4-6 weeks after planting (Schonbeck, 2015).

When growing fruit rest on BDMs, problems can arise with the durability of the mulch because of the weight and pressure imposed by the fruit, and the quality of the fruit because of adhering mulch fragments. Limpus (2012) reported that melon, tomato, pepper, and eggplant fruit resting on the surface of plastic BDMs can cause the mulch to split, although growers did not indicate the splitting to be widespread. BDM fragments

\footnotetext{
Received for publication 17 Oct. 2017. Accepted for publication 7 Jan. 2018.

This article is based on work that is supported by the National Institute of Food (NIFA) and Agriculture, U.S. Department of Agriculture, under award number 2014-51181-22382, and NIFA Hatch project 1008680 .

We appreciate technical assistance by Ed Scheenstra, Lydia Tymon, and Babette Gundersen, Washington State University (WSU), and B.J. DeLozier and Cody Fust, University of Tennessee (UT). We thank Arnold Saxton (UT) for statistical advice, and Lisa DeVetter (WSU) and Douglas Hayes (UT) for thorough review of the manuscript.

Any opinions, findings, conclusions, or recommendations expressed in this article are those of the authors and do not necessarily reflect the view of the U.S. Department of Agriculture.

${ }^{1} \mathrm{PhD}$ Candidate.

${ }^{2}$ Associate Professor and Vegetable Horticulturist.

${ }^{3}$ Research Specialist and Horticulturist.

${ }^{4}$ Professor and Extension Plant Pathologist.

${ }^{5}$ Professor and Horticulturist.

${ }^{6}$ Corresponding author. E-mail: shuresh.ghimire@ wsu.edu.
}

did adhere to the surface of the tomato and pepper fruit, but the adhering mulch was easily removed. However, C.A. Miles (unpublished data) reported BDM fragments adhering to the surface of watermelon (Citrullus lanatus) fruit that could not be wiped off.

Fruit quality is another important consideration for crops grown with BDM. There was no difference in fruit TSS because of mulch when Rangarajan and Ingall (2006) measured the quality of 'Athena' muskmelon grown with four plastic BDMs and a PE mulch. Filippi et al. (2011) evaluated melon grown with two BDMs (black and green, both Mater-Bi based) and a PE mulch in Italy in 2004, and then again with three plastic BDMs (two green and one black) and a PE mulch in 2005. BDMs produced higher yield than PE mulch, whereas fruit TSS and percent dry matter (DM) content were higher with BDMs in 2004, but not in 2005 .

Although several studies have evaluated BDM deterioration, weed pressure, and crop yield and quality, no studies have used pie pumpkin as a test crop. Pie pumpkin and similar cucurbit crops are economically important crops and are grown worldwide. The selection of pie pumpkin as the test crop in this study allowed for nearly identical planting and harvest dates at Mount Vernon and Knoxville test sites, despite their major climate differences. Pumpkin leaves and stems have enlarged, rigid and sharp trichomes that are abrasive and could contribute to mulch tearing. As pumpkin fruit mature and become heavier, there can be substantial fruit-tomulch contact that might accelerate mulch deterioration through splitting, and/or lead to mulch adhesion on fruit and fruit quality losses. The fruit is often stored for several months, especially by fresh-market growers, and it is uncertain if a BDM has an impact on the quality of stored fruit. The objectives of the current study were to evaluate the deterioration of five BDMs throughout two pie pumpkin growing seasons (June-September in 2015 and 2016) in two diverse regions of the United States (Mount Vernon, WA and Knoxville, TN), and to compare these BDMs with PE mulch and bare ground for weed control and impact on pie pumpkin total fruit yield, marketable yield, and fruit quality at harvest and during 8-week storage.

\section{Materials and Methods}

Experimental locations. This study was carried out at two locations in 2015 and 2016: the Washington State University (WSU) Northwestern Washington Research and Extension Center at Mount Vernon, WA $\left(48^{\circ} 43^{\prime} 24^{\prime \prime} \mathrm{N}, 122^{\circ} 39^{\prime} 09^{\prime \prime} \mathrm{W}\right.$, elevation $\left.6 \mathrm{~m}\right)$ and the University of Tennessee, East Tennessee AgResearch and Education Center at Knoxville, TN $\left(35^{\circ} 52^{\prime} 52^{\prime \prime} \mathrm{N}, 83^{\circ} 55^{\prime} 27^{\prime \prime} \mathrm{W}\right.$, elevation $270 \mathrm{~m}$ ). The Mount Vernon field site was located in the maritime Pacific Northwest, where the summer climate is mild and humid with $15{ }^{\circ} \mathrm{C}$ average daily temperature, $82 \%$ relative humidity $(\mathrm{RH})$, and $150 \mathrm{~mm}$ rainfall (20-year average; AgWeatherNet, 2016). The site has poorly drained Skagit silt loam soil characterized as a fine-silty, mesic Fluvaquentic Endoaquepts with a pH of 6.2 and $2.8 \%$ organic matter. The Knoxville field site was located in the subtropical Southeast United States with a hot and humid summer climate with $23{ }^{\circ} \mathrm{C}$ average daily temperature, $73 \%$ average $\mathrm{RH}$, and $421 \mathrm{~mm}$ rainfall (30-year average; Arguez et al., 2010). The site has moderately well drained Shady-Whitwell complex soil characterized as a fine-loamy, thermic Typic Hapludult with a $\mathrm{pH}$ of 6.4 and $1.3 \%$ organic matter. At Mount Vernon, the experiment was preceded by a clover (Trifolium sp. L.) winter cover crop in 2015 and a winter wheat (Triticum aestivum L.) cover crop in 2016, whereas at Knoxville, a winter wheat cover crop preceded the experiment both years.

Experimental design and planting. The experiment used a completely randomized split-split-plot design with four replications. Location was the main plot because it was applied to all the blocks, mulch treatment was the subplot because it was applied to plots, and year was the sub-subplot because it was applied within a plot; treatment plot assignments did not change across the years to avoid cross-treatment mulch and soil contamination. Seven subplot mulch treatments (Table 1) were randomized within each main plot in 2015. At both locations, raised beds were $15-20 \mathrm{~cm}$ high and $0.8 \mathrm{~m}$ wide. Mulch was laid by machine (Model 2600 Bed Shaper; Rain-Flo Irrigation, East Pearl, PA) in all plots at the time when beds were shaped, except for Naturecycle in 2015 that was folded in half longitudinally during manufacturing, and therefore, hand laying was required. While laying all the mulches including the paper mulch, the guide wheels of the mulch layer barely rested on the mulch or floated just above the mulch so as to guide the mulch into the furrows that were opened up by the mulch layer, but the wheels did not apply pressure to the mulch. 'Cinnamon Girl' pie pumpkin (Johnny's Selected Seed, Winslow, ME) was planted at both locations over both years, and was chosen because of its fruit weight $(1-2.5 \mathrm{~kg})$ and short-vine habit that could maximize potential fruit-to-mulch contact. Plots were five rows wide and $9 \mathrm{~m}$ long, and beds were spaced $2.4 \mathrm{~m}$ center-tocenter. In-row spacing was $0.9 \mathrm{~m}$ with plants in a single row, off-set of center in each bed with 10 plants/row and 50 plants/plot. Pumpkins were transplanted at Mount Vernon and direct-seeded at Knoxville following common grower practices in each region. At Mount Vernon, pumpkins were seeded in the greenhouse in 72-cell trays on 7 May 2015 and 9 May 2016, and transplanted to the field on 28-29 May 2015, and 31 May 2016. On the day after transplanting, the remaining seedlings were moved to $10 \mathrm{~cm}$ pots to be used as replacement plants. At Knoxville, on the same day as field seeding, 15 June 2015 and 2016, pumpkins were seeded in 72-cell trays in the greenhouse and these transplants were used to fill gaps in the plots as needed. 
Table 1. Mulch treatments evaluated in 'Cinnamon Girl' pumpkin grown at Mount Vernon, WA and Knoxville, TN in 2015 and 2016. Thickness, ingredient(s) and biobased content information was obtained from each mulch manufacturer.

\begin{tabular}{lllclc}
\hline Mulch treatment & \multicolumn{1}{c}{ Manufacturer } & Color & Thickness $(\mathrm{mm})$ & \multicolumn{2}{c}{ Key product ingredient(s) } \\
\hline BioAgri & BioBag Americas, Inc., Dunedin, FL & Black & 0.0180 & Mater-Bi grade EF04P (starch-copolyester blend) & Biobased (\%) $)^{2}$ \\
Exp. PLA/PHA & Experimental film & Black & 0.0250 & IngeoPLA & 86 \\
Naturecycle & Custom Bioplastics, Burlington, WA & Black & 0.0254 & Starch-polyester blend & $\geq 20$ \\
Organix & Organix Solutions, Maple Grove, MN & Black & 0.0178 & BASF Ecovio M2351 (PBAT + PLA) & 10 \\
Polyethylene & Filmtech, Allentown, PA & Black & 0.0254 & Polyethylene & $<1$ \\
WeedGuardPlus & Sunshine Paper Co. & Brown & 0.2400 & Cellulose & 100 \\
\hline
\end{tabular}

${ }^{\mathrm{z}}$ Composition (\%) of mulch that is from biological products or renewable materials; biobased content can be important, for example the USDA National Organic Program requires a biodegradable mulch to be $100 \%$ biobased to allow its use in organic agriculture.

${ }^{\mathrm{y}}$ Not available in market, prepared for this study by Metabolix, Inc., Cambridge, MA.

PLA = polylactic acid; PHA = poly(hydroxyalkanoate) PBAT = poly (butylene adipate- $c o$-terephthalate $)$.

At both locations, missing plants in the field were replaced up to 4 weeks after seeding/ transplanting, when transplant size was equivalent to the size of plants in the field.

Fertilizer and irrigation. Fertilizer application was performed according to recommended practices for pumpkin in each region. At Mount Vernon, fertilizer was applied before planting at the rate of $117 \mathrm{~kg} \mathrm{~N} / \mathrm{ha}$, $51 \mathrm{~kg} \mathrm{P} / \mathrm{ha}, 48 \mathrm{~kg} \mathrm{~K} / \mathrm{ha}, 16 \mathrm{~kg} \mathrm{~S} / \mathrm{ha}$, and $11 \mathrm{~kg}$ $\mathrm{Ca} / \mathrm{ha}$ in 2015; and $120 \mathrm{~kg} \mathrm{~N} / \mathrm{ha}, 52 \mathrm{~kg} \mathrm{P} / \mathrm{ha}$, $50 \mathrm{~kg} \mathrm{~K} / \mathrm{ha}, 16 \mathrm{~kg} \mathrm{~S} / \mathrm{ha}$, and $12 \mathrm{~kg} \mathrm{Ca} / \mathrm{ha}$ in 2016. At Knoxville both years, fertilizer was applied before planting and additionally through fertigation (four times in 2015 and six times in 2016), for total nutrient application of $89.6 \mathrm{~kg} \mathrm{~N} / \mathrm{ha}, 24.5 \mathrm{~kg} \mathrm{P} / \mathrm{ha}, 107.8 \mathrm{~kg}$ $\mathrm{K} / \mathrm{ha}$, and $14.5 \mathrm{~kg} \mathrm{Ca} / \mathrm{ha}$ in 2015 ; and 112.2 $\mathrm{kg} \mathrm{N} / \mathrm{ha}, 24.5 \mathrm{~kg} \mathrm{P} / \mathrm{ha}, 138.4 \mathrm{~kg} \mathrm{~K} / \mathrm{ha}$, and $28.7 \mathrm{~kg} \mathrm{Ca} / \mathrm{ha}$ in 2016 . At both locations, drip irrigation tape (T-Tape, Model 508-08-340, $0.20 \mathrm{~mm}, 20 \mathrm{~cm}$ emitter spacing, $4.23 \mathrm{~L} / \mathrm{min} /$ $100 \mathrm{~m}$ flowrate, San Diego, CA) was laid simultaneously with mulch during bed shaping. Drip irrigation rate was based on moisture sensors (5TM; Decagon Devices, Inc., Pullman, WA) installed at each location in row 3 of the PE mulch treatment in one replicate block at 10 and $20 \mathrm{~cm}$ depths, and data were recorded with data loggers (EM50G; Decagon Devices, Inc.).

Weather data. Air temperature, solar radiation, $\mathrm{RH}$, and rainfall data were collected from the WSU AgWeatherNet station located $\approx 140 \mathrm{~m}$ from the field site at Mount Vernon. At Knoxville, air temperature and rainfall were collected from the U.S. National Oceanic and Atmospheric Administration station located $12 \mathrm{~km}$ from the field site, and solar radiation was collected from the Plant Sciences Unit weather station located near the field site, and RH was recorded from a weather station (VP-3; Decagon Devices, Inc.) installed $10 \mathrm{~m}$ away from the experimental site. Soil temperature and moisture sensors (5TM; Decagon Devices, Inc.) were installed in row 3 of each plot in one replicate block at $10 \mathrm{~cm}$ and $20 \mathrm{~cm}$ depths and data were recorded at $60 \mathrm{~s}$ intervals and averaged hourly using data loggers (EM50G; Decagon Devices, Inc.) at both locations.

Weed management. The planting holes in mulch treatments and a $5 \mathrm{~cm}$ diameter area around each plant in the bare ground treatment were hand weeded as needed throughout the growing season at both locations. At Mount Vernon, herbicides (Curbit EC 3.5
$\mathrm{L} \cdot \mathrm{ha}^{-1}$, Gramoxone SL $2.3 \mathrm{~L} \cdot \mathrm{ha}^{-1}$, In-Place $239.6 \mathrm{~g} \cdot \mathrm{L}^{-1}$, Gly Star Original $372.7 \mathrm{~mL} \cdot \mathrm{ha}^{-1}$, and R-56 $190 \mathrm{~mL} \cdot \mathrm{ha}^{-1}$ ) were applied to alleys posttransplant in 2015. No herbicide was applied pre- or posttransplanting in 2016. At Knoxville both years, postemergence herbicides (2.34 L.ha ${ }^{-1}$, Dual II Magnum $1.47 \mathrm{~L} \cdot \mathrm{ha}^{-1}$, and Command $1.86 \mathrm{~L} \cdot \mathrm{ha}^{-1}$; RoundUp WeatherMax, Monsanto, St. Louis, MI) were applied to alleys between the raised beds. The bare ground plots were the weedy control for the whole growing season in 2015 and until most of the critical weed control period had passed in 2016. In 2016, weed pressure became severe in bare ground plots at both locations, thus those plots were hand weeded 35 and $56 \mathrm{~d}$ after transplanting at Mount Vernon and $30 \mathrm{~d}$ after planting at Knoxville.

Mulch deterioration ratings and weed measurement. To evaluate mulch deterioration over the crop season, the PSE of each mulch treatment was recorded in the center $1 \mathrm{~m}$ of the center row of each plot two times per month. At each location, the same person recorded the data both years. PSE was assessed such that $0 \%$ represented soil that was completely covered and $100 \%$ represented fully exposed soil. Ratings were in $1 \%$ increments up to $20 \%$ PSE and in 5\% increments thereafter. Weeds were collected from the center $1 \mathrm{~m}$ of the second or fourth bed (randomly selected in each plot each year) three times during the pumpkin growing season: 2 weeks posttransplanting, midseason, and 2 weeks before harvest at both locations in 2015. In 2016, data collection was repeated at Knoxville, whereas at Mount Vernon, data only were collected 2 weeks posttransplanting because weeds were managed in bare ground plots thereafter and there were essentially no weeds in the mulched plots. Both years, weeds were clipped at the soil surface, dried at $60^{\circ} \mathrm{C}$ for $48 \mathrm{~h}$, and total dry weight was recorded.

Fruit harvest, yield, and quality. Pumpkins were harvested on 16 Sept. 2015 and 21 Sept. 2016 at Mount Vernon and on 14-15 Sept. 2015 and 6 Sept. 2016 at Knoxville. All fruit were harvested from the center $8 \mathrm{~m}$ (eight plants) of the center row in each plot. All fruit that were immature, less than $10 \mathrm{~cm}$ diameter, diseased, or rotten were discarded. The number and total weight of harvested fruit and the number of fruit with mulch adhesion (fragments $>1 \mathrm{~cm}^{2}$ ) were recorded both years; but, the weight of fruit with mulch adhesion was recorded only in 2016. Fruit quality was measured for five randomly selected fruit from each plot at harvest, and an additional 25 randomly selected fruit per plot were placed in storage for postharvest quality assessments, which were performed on five randomly selected fruit every 2 weeks for 8 weeks. At both locations, storage bins were blocked by replication within a pole barn, and fruit were stored under ambient conditions with temperature and humidity measured (Hobo Onset V 3.7.8; Onset Computer Corp., Bourne, MA) every $15 \mathrm{~min}$ throughout the storage period. For each postharvest assessment, fruit were cut in half from stem end to blossom end, and an $\approx 1$ $\mathrm{cm}$ slice was taken from one of the halves, placed in a labeled plastic bag and frozen $\left(-8^{\circ} \mathrm{C}\right)$ for at least $48 \mathrm{~h}$. The samples were thawed at room temperature $\left(23^{\circ} \mathrm{C}\right)$ for at least $24 \mathrm{~h}$, squeezed gently until two to three drops of juice flowed onto a temperature compensating refractometer (Palm Abbe PA201, Cleveland, $\mathrm{OH}$ at Mount Vernon; Reichert AR200, Depew, NY at Knoxville), and the TSS value was recorded. The refractometer was rinsed using deionized water and blotted dry between each sample. A second slice of fruit $\approx 1 \mathrm{~cm}$ thick and weighing at least $50 \mathrm{~g}$ was cut as described previously, and the fresh weight recorded. These samples were dried at $65^{\circ} \mathrm{C}$ for $96 \mathrm{~h}$ and the percent DM calculated.

Data analysis. All data were subjected to analysis of variance using generalized linear mixed model (GLIMMIX) procedure in SAS (Statistical Analysis System Version 9.2 for Windows; SAS Institute, Cary, NC). Data were analyzed as a completely randomized split-split-plot design with repeated measures for PSE, TSS, and percent DM data, which were measured several times over the pumpkin growing and storage season. The slice statement was used to subdivide means by observation dates to simplify means comparisons. As weed management practices varied across locations and years, weed data were analyzed separately for each year and each location. The assumptions of normality and homogeneity of variances were assessed using the Shapiro-Wilk test $(W>0.80)$ and the Levene's test $(\alpha=0.05)$, respectively. The MMAOV macro (Saxton, 2010) in SAS was used to build all PROC GLIMMIX procedures. Fisher's least significant difference test at an alpha level 0.05 was used to compare treatment means for significant 
differences. No transformation satisfied the assumptions of normality and homogeneity of variance for PSE and weed data, therefore a nonparametric transformation was applied for these data using PROC RANK in SAS, but means are reported based on the raw data. Data are presented by location when treatment and location interaction was significant, and data are presented by year when treatment and year interaction was significant.

\section{Results}

Weather data. At Mount Vernon, the 2-year average daily air temperature for the pumpkin growing season (June-September) was $17{ }^{\circ} \mathrm{C}$, RH was $76 \%$, total solar radiation was $2260 \mathrm{MJ} \cdot \mathrm{m}^{-2}(9 \%$ greater in 2015 than 2016), and total rainfall was $140 \mathrm{~mm}(90 \mathrm{~mm}$ in 2015 and $190 \mathrm{~mm}$ in 2016) (Table 2). At Knoxville, the 2-year average daily air temperature was $25^{\circ} \mathrm{C}$, RH was $80 \%$, total solar radiation was $1907 \mathrm{MJ} \cdot \mathrm{m}^{-2}$ (14\% greater in 2015 than 2016), and total rainfall was $239 \mathrm{~mm}(354 \mathrm{~mm}$ in 2015 and $123 \mathrm{~mm}$ in 2016). During pumpkin storage at Mount Vernon in 2015 and 2016 (SeptemberNovember), the average ambient temperature was 18 and $15{ }^{\circ} \mathrm{C}$, and the average $\mathrm{RH}$ was $70 \%$ and $71 \%$, respectively (Fig. 1). At Knoxville during pumpkin storage, the average ambient temperature was 18 and $22{ }^{\circ} \mathrm{C}$, and the average $\mathrm{RH}$ was $82 \%$ and $61 \%$ in 2015 and 2016, respectively.

The 2-year average soil temperature during the pumpkin growing season at Mount Vernon was $20.5^{\circ} \mathrm{C}$ at $10 \mathrm{~cm}$ depth $\left(1.8^{\circ} \mathrm{C}\right.$ higher in 2015 than 2016) (Table 2). At Knoxville, the 2-year average soil temperature was $26.8^{\circ} \mathrm{C}$ at $10 \mathrm{~cm}$ depth $\left(2.0^{\circ} \mathrm{C}\right.$ lower in 2015 than 2016). In 2015 at Mount Vernon, soil temperature was $3{ }^{\circ} \mathrm{C}$ lower for bare ground and WeedGuardPlus, and $1.8^{\circ} \mathrm{C}$ lower for all plastic BDMs, compared with PE $\left(23.3{ }^{\circ} \mathrm{C}\right)$. In 2016 , soil temperature was $1{ }^{\circ} \mathrm{C}$ lower for bare ground, WeedGuardPlus and Organix as compared with all other plastic mulches $\left(20{ }^{\circ} \mathrm{C}\right.$ on average $)$. In 2015 at Knoxville, soil temperature also was the lowest for bare ground and WeedGuardPlus $\left(25.3^{\circ} \mathrm{C}\right.$ on average), but was the highest for Organix $\left(26.9^{\circ} \mathrm{C}\right)$. In 2016 , soil temperature was the lowest for WeedGuardPlus (26.7 $\left.{ }^{\circ} \mathrm{C}\right)$ compared with all other treatments ( $27.8{ }^{\circ} \mathrm{C}$ on average). Soil temperature at 20 $\mathrm{cm}$ depth was similar as at $10 \mathrm{~cm}$, and followed the same trends (data not reported).

Percent soil exposure. PSE differed because of treatment and year, and because of interacting effects of treatment and year; treatment and location; and treatment, year, and location $(P<0.0001$ for all). However, PSE did not differ because of location, and there was no interaction between location and year. PSE increased over sampling time at both locations over both years $(P<0.05$ for all). At Mount Vernon in 2015, PSE was the highest for Naturecycle compared with other mulch treatments, and reached $61 \%$ by the end of the season (Fig. 2). PSE for PE, Exp. PLA/PHA, WeedGuardPlus, and Organix

Table 2. Environmental and soil temperature data during the pumpkin growing season at Mount Vernon, WA and Knoxville, TN in 2015 and 2016.

\begin{tabular}{lccccc}
\hline & \multicolumn{2}{c}{ Mount Vernon $^{z}$} & & \multicolumn{2}{c}{ Knoxville $^{\mathrm{y}}$} \\
\cline { 2 - 3 } Environmental parameters & 2015 & 2016 & & 2015 & 2016 \\
\hline Average daily air temperature $\left({ }^{\circ} \mathrm{C}\right)$ & 17.4 & 16.4 & & 24.9 & 25.9 \\
Average daily maximum air temperature $\left({ }^{\circ} \mathrm{C}\right)$ & 23.7 & 22.2 & & 30.3 & 32.5 \\
Average daily minimum air temperature $\left({ }^{\circ} \mathrm{C}\right)$ & 11.5 & 11.2 & & 19.6 & 20.8 \\
Total solar radiation $\left(\mathrm{MJ} \cdot \mathrm{m}^{-2}\right)$ & 2,359 & 2,161 & & 2,033 & 1,781 \\
Relative humidity $(\%)$ & 75.7 & 77.1 & & 81.6 & 77.9 \\
Total rainfall $(\mathrm{mm})$ & 90 & 190 & & 354 & 123 \\
Soil temperature $\left({ }^{\circ} \mathrm{C}\right)^{\mathrm{x}}$ & & & & \\
Bare ground & 20.3 & 18.8 & & 25.2 & 27.7 \\
BioAgri & 21.9 & 20.1 & & 25.8 & 28.1 \\
Exp. PLA/PHA & 21.8 & 19.7 & & 26.2 & 27.9 \\
Naturecycle & 21.5 & 20.0 & & 25.4 & 27.9 \\
Organix & 20.9 & 19.1 & & 26.9 & 28.3 \\
Polyethylene & 23.3 & 20.1 & & 26.1 & 28.3 \\
WeedGuardPlus & 20.0 & 19.1 & & 25.3 & 26.7 \\
Average & 21.4 & 19.6 & 25.8 & 27.8 \\
\hline
\end{tabular}

${ }^{\mathrm{z}}$ Data from Washington State University AgWeatherNet Station located $\approx 40 \mathrm{~m}$ from the field site.

${ }^{y}$ All 2015 data were collected from the National Oceanic and Atmospheric Administration Station at McGhee Tyson Airport, located $12 \mathrm{~km}$ from field site, except solar radiation, which was recorded at the Plant Sciences Unit Weather Station located near the experiment, and humidity, which was acquired from sensors (VP-3; Decagon Devices, Inc.) at the field site, 5 Aug. to 16 Sept. 2015. In 2016, all data were collected at a Decagon Weather Station, located $10 \mathrm{~m}$ from the field site.

${ }^{\mathrm{x}}$ Soil temperature at $10 \mathrm{~cm}$ depth was measured from 30 May to 16 Sept. 2015 and 1 June to 20 Sept. 2016 at Mount Vernon, and 17 June to 16 Sept. 2015 and 16 June to 5 Sept. 2016 at Knoxville.

${ }^{\mathrm{w}}$ Experimental film made with polylactic acid (PLA)/polyhydroxyalkanoate (PHA) polymers.
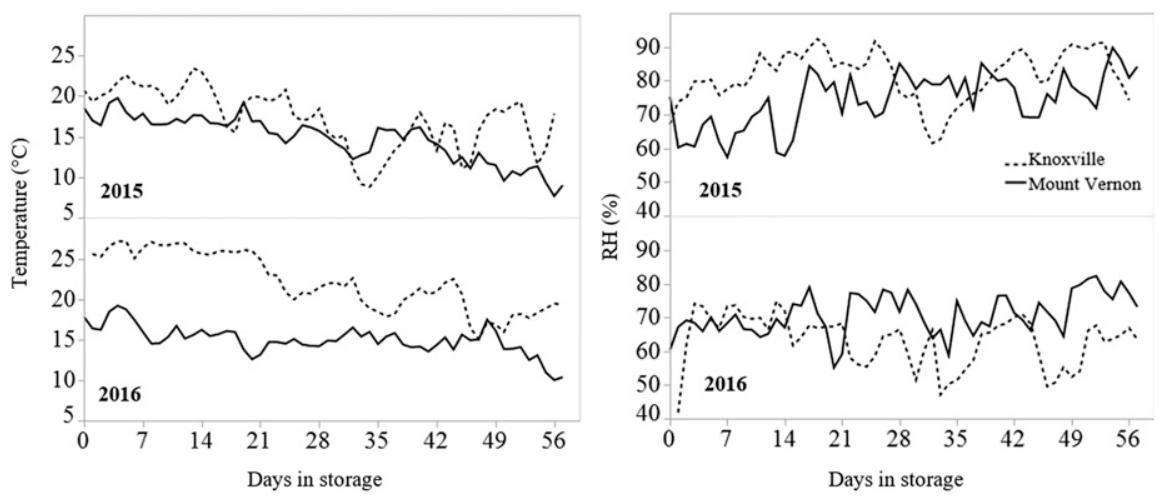

Fig. 1. Temperature $\left({ }^{\circ} \mathrm{C}\right)$ and relative humidity (RH \%) during 8 weeks of 'Cinnamon Girl' pumpkin storage at Mount Vernon, WA and Knoxville, TN in 2015 and 2016.

was low throughout the growing season and reached $0.3 \%$ to $8 \%$ by the end of the season. In 2016, PSE was low for all the mulch treatments $(0 \%$ to $6.5 \%)$. At Knoxville in 2015 , Naturecycle reached $100 \%$ PSE 3 weeks after pumpkin sowing, WeedGuardPlus reached $100 \%$ PSE 1 month before harvest, and BioAgri reached 36\% PSE at the end of the growing season (Fig. 2). PSE for PE, Exp. PLA/PHA and Organix was low throughout the growing season and reached $2 \%$ to $7 \%$ by the end of the season. In 2016, PSE was the lowest for PE mulch (5.5\%), whereas PSE for all other mulch treatments was $14.3 \%$ to $25 \%$.

Weed measurement. Predominant weeds at Mount Vernon were pigweed (Amaranthus sp. L.), chickweed (Stellaria media L.), and common lambsquarter (Chenopodium sp. L.), whereas predominant weeds at Knoxville were nutsedge (Cyperus sp.), carpetweed (Mollugo sp. L.), and goosegrass (Galium aparine L.). At Mount Vernon in 2015, dry weight of weeds was not measured at 2 weeks after transplanting, but at midseason and 2 weeks before harvest, there were weeds ( 388 and $475 \mathrm{~g} \cdot \mathrm{m}^{-2}$, respectively) only in bare ground except $0.1 \mathrm{~g} \cdot \mathrm{m}^{-2}$ of weeds in Naturecycle 2 weeks before harvest $(P=0.04$ and $P<0.0001$, respectively). Also, in 2016, there were weeds (dry weight $15 \mathrm{~g} \cdot \mathrm{m}^{-2}$ ) only in bare ground treatment 2 weeks after transplanting $(P<0.0001)$. At Knoxville in 2015 , dry weight of weeds was higher for the bare ground treatment and Naturecycle 2 weeks after transplanting (59 and $9 \mathrm{~g} \cdot \mathrm{m}^{-2}$, respectively) $(P=0.0005)$, midseason (199 and $33 \mathrm{~g} \cdot \mathrm{m}^{-2}$, respectively) $(P<0.0001)$, and 2 weeks before harvest ( 71 and $25 \mathrm{~g} \cdot \mathrm{m}^{-2}$, respectively) $(P=0.0002)$ compared with all other treatments, where there were minimal weeds $\left(0-13 \mathrm{~g} \cdot \mathrm{m}^{-2}\right)$. In 2016, dry weight of weeds was high for the bare ground treatment 2 weeks after transplanting $\left(91 \mathrm{~g} \cdot \mathrm{m}^{-2}\right)$ $(P<0.0001)$, midseason $\left(56 \mathrm{~g} \cdot \mathrm{m}^{-2}\right)(P<$ $0.0001)$, and 2 weeks before harvest (168 $\left.\mathrm{g} \cdot \mathrm{m}^{-2}\right)(P<0.0001)$, whereas there were minimal weeds in all the mulched treatments $\left(0.8-17 \mathrm{~g} \cdot \mathrm{m}^{-2}\right)$. 
Fruit yield. Pumpkin yield differed because of treatment $(P<0.0001)$, and the yield was influenced by interacting effects of treatment and location $(P=0.009)$, and location and year $(P<0.0001)$. However, the yield did not differ because of location and year, and there were no interactions between treatment and year; and treatment, location, and year. At Mount Vernon, overall mean pumpkin yield for both years was 18.1 t. ha ${ }^{-1}$, whereas yield was higher in the PE, Exp. PLA/PHA, BioAgri, and Naturecycle treatments compared with the bare ground and WeedGuardPlus treatments (Table 3). At Knoxville, overall mean pumpkin yield for both years was $17.7 \mathrm{t} \cdot \mathrm{ha}^{-1}$, and yield did not differ because of treatment. The average pumpkin yield at Mount Vernon for all treatments combined was higher in 2015 than in 2016 (20.1 and $16.1 \mathrm{t} \cdot \mathrm{h}^{-1}$, respectively), but was lower in 2015 than in 2016 at Knoxville (15.7 and $19.7 \mathrm{t} \cdot \mathrm{h}^{-1}$, respectively).

The number of fruit per hectare differed because of treatment and location, and there were interactions between treatment and location, location and year $(P<0.0001$ for all), and treatment, location, and year $(P=0.015)$. However, the number of fruit did not differ because of year, and there was no interaction between treatment and year. At Mount Vernon for both years combined, the number of fruit per hectare was higher in the PE treatment than for the other treatments, and the number of fruit in all four plastic BDM treatments was significantly higher than the WeedGuardPlus treatment; the bare ground treatment had fewer fruit than all other treatments (Fig. 3). At Knoxville, the number of fruit per hectare did not differ because of mulch treatment. At Mount Vernon, the average number of fruit for all the treatments combined was higher in 2015 than in $2016(15,891$ and 12,901 fruit/ha, respectively), whereas at Knoxville, the average number of fruit for all the treatments was lower in 2015 than in 2016 (10,390 and 14,157 fruit/ha, respectively).

Mulch adhesion. Percentage of fruit with mulch adhesion differed because of treatment and location, and there was an interaction between treatment and location $(P<0.0001$ for all). All other two-way and three-way interactions were insignificant. At both locations over both years, there was no mulch adhesion on fruit in the PE mulch treatment. At Mount Vernon, $0.4 \%$ of the fruit in the Exp. PLA/PHA treatment had mulch adhesion, whereas all the other BDM treatments
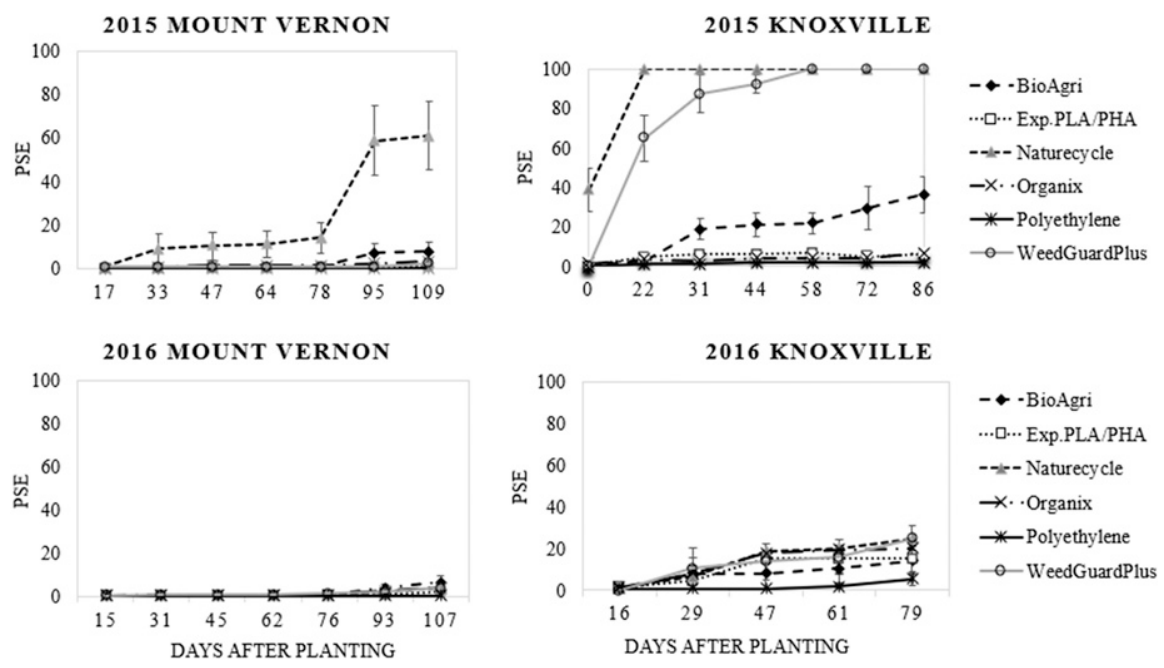

Fig. 2. Percent soil exposure (PSE) for each mulch treatment over the pumpkin growing season at Mount Vernon, WA and Knoxville, TN in 2015 and 2016. The error bars represent two sEs of mean. PSE was measured such that $0 \%$ represented soil that was completely covered and $100 \%$ represented fully exposed soil; rating was in $1 \%$ increments until $20 \%$ PSE, and in $5 \%$ increments thereafter.

Table 3. Total fruit yield (t.ha ${ }^{-1}$ ) for 'Cinnamon Girl' pumpkin in 2015 and 2016 (years combined), and fruit yield with mulch adhesion ( $\mathrm{t} \cdot \mathrm{ha}^{-1}$ ) in 2016 at Mount Vernon, WA and Knoxville, TN.

\begin{tabular}{|c|c|c|c|c|}
\hline & \multicolumn{2}{|c|}{ Total pumpkin yield $\left(\mathrm{t} \cdot \mathrm{ha}^{-1}\right)$} & \multicolumn{2}{|c|}{ Pumpkin yield (t.ha ${ }^{-1}$ ) with mulch adhesion } \\
\hline & Mount Vernon & Knoxville & Mount Vernon & Knoxville \\
\hline Bare ground & $8.70 \mathrm{~d}^{\mathrm{z}}$ & 15.27 & NA & NA \\
\hline BioAgri & $20.86 a b$ & 18.79 & $8.13 \mathrm{~b}$ & 1.29 \\
\hline Exp. PLA/PHA ${ }^{y}$ & $20.96 \mathrm{ab}$ & 16.34 & $0 \mathrm{c}$ & 0.32 \\
\hline Naturecycle & $19.92 \mathrm{ab}$ & 17.28 & $10.77 \mathrm{a}$ & 1.30 \\
\hline Organix & $18.38 \mathrm{bc}$ & 19.86 & $8.90 \mathrm{ab}$ & 1.79 \\
\hline Polyethylene & $22.75 \mathrm{a}$ & 20.39 & $0 \mathrm{c}$ & 0 \\
\hline WeedGuardPlus & $15.28 \mathrm{c}$ & 16.16 & $7.57 \mathrm{~b}$ & 0.82 \\
\hline$P$-value & $<0.0001$ & 0.27 & $<0.0001$ & 0.07 \\
\hline
\end{tabular}

${ }^{\mathrm{z}}$ Treatment means compared using Fisher's least significant difference at $\alpha=0.05$. Treatment means followed by the same letter within a column are not significantly different.

${ }^{\mathrm{y}}$ Experimental film made with polylactic acid (PLA)/polyhydroxyalkanoate (PHA) polymers.

$\mathrm{NA}=$ not applicable. had $42 \%$ to $59 \%$ fruit with mulch adhesion (Fig. 3). At Knoxville, all BDM treatments had $3 \%$ to $12 \%$ fruit with mulch adhesion. The yield (weight) of pumpkins with mulch adhesion (recorded in 2016 only) differed because of treatment $(P<0.0001)$, location $(P=0.001)$, and there was an interaction between treatment and location $(P=0.001)$. At Mount Vernon, yield of pumpkins with mulch adhesion comprised $48 \%$ of the total yield for all the four mulch treatments that adhered to fruit (Table 3). By contrast, at Knoxville, most of the pumpkin fruit set was outside the mulched bed because of the longer vine growth, and there was no significant difference in the yield of pumpkins with mulch adhesion; $6 \%$ of the total yield for the five mulch treatments had mulch fragments adhered to the fruit.

Postharvest fruit quality. TSS of fruit did not differ because of treatment, but differed because of year $(P<0.0001)$ and location $(P=0.02)$. There was an interaction between treatment and year $(P=0.04)$, and location and year $(P<0.0001)$. However, there was no interaction between treatment and location, and treatment, location and year. TSS was not influenced by the interaction of mulch treatment and sampling interval. Overall TSS was higher at Mount Vernon (8.10 ${ }^{\circ}$ Brix) than Knoxville (7.89), and higher in 2015 (8.13) than 2016 (7.87). Although TSS in 2015 did not differ because of mulch treatment, in 2016 TSS was higher in fruit grown on PE, Organix, Naturecycle, and BioAgri than for fruit grown on bare ground across both locations (Table 4). TSS increased from harvest to 2 weeks of storage and then declined over the storage period, such that TSS at 8 weeks was the same as TSS at harvest (data not shown). DM of fruit did not differ because of mulch treatment either year, and did not differ over 8 weeks of storage (data not presented).

\section{Discussion}

PE mulch and plastic BDMs raised soil temperature by 1 to $1.8{ }^{\circ} \mathrm{C}$ at $10 \mathrm{~cm}$ depth compared with bare ground and WeedGuardPlus, which is in line with Cowan et al. (2014) and Miles et al. (2012). Deterioration of the BDMs varied by location and year. In 2015, deterioration of Naturecycle was substantial and started primarily along the center fold line shortly after laying, even before planting, because of heavy rainfall coupled with strong wind. Naturecycle in 2016 had the same formulation as in 2015, but was not folded, and very low PSE occurred. This observation suggests that the higher PSE in 2015 was due to the fold. PSE for WeedGuardPlus and BioAgri tended to be greater at Knoxville than Mount Vernon in 2015, likely because of heavy rainfall at Knoxville early in the season. Changes in the physicochemical properties of the mulches due to environmental weathering during the 2015 crop growing season are reported elsewhere (Hayes et al., 2017). In 2016, PSE at both locations was relatively low for all treatments by the end of 


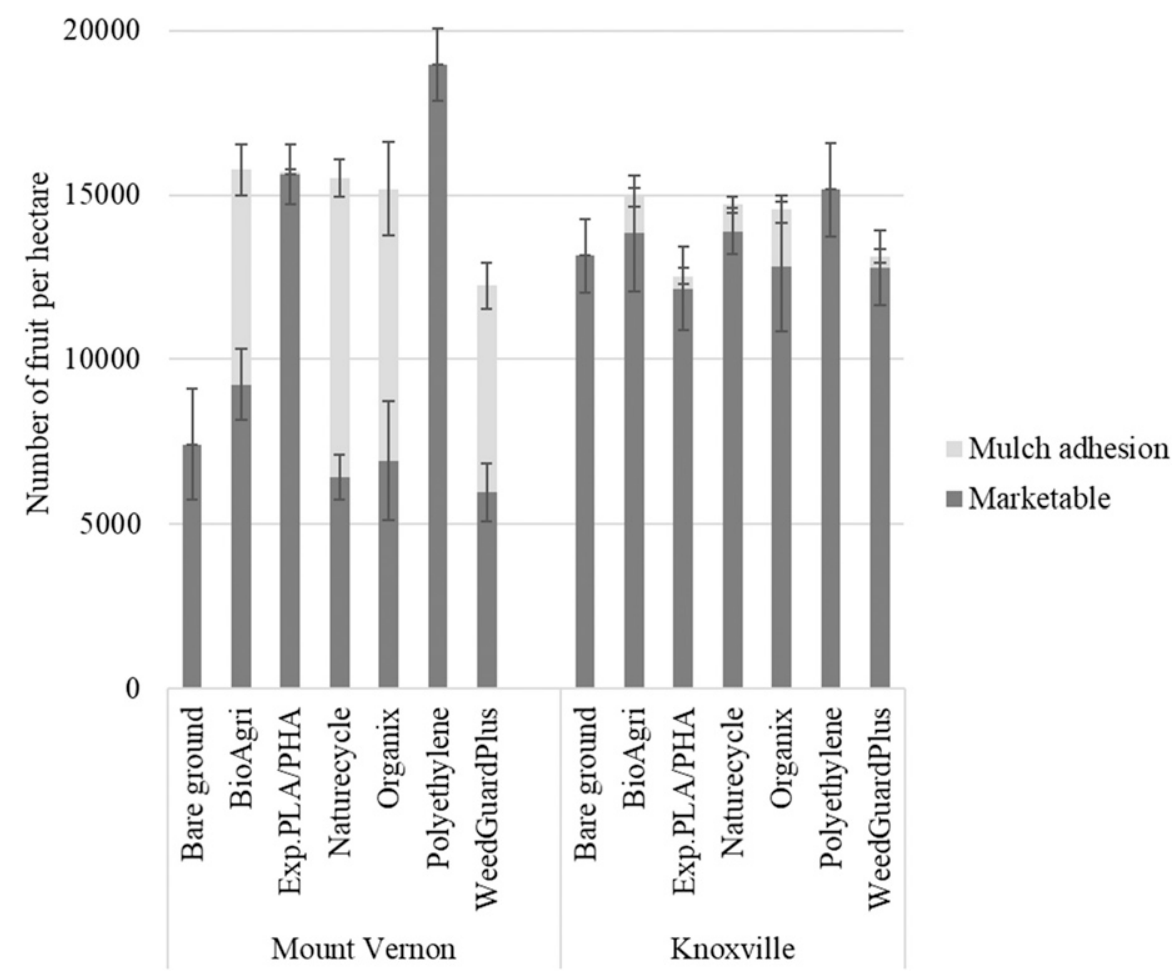

Fig. 3. Number of marketable fruit and number of fruit with mulch adhesion per hectare of 'Cinnamon Girl' pumpkin grown at Mount Vernon, WA and Knoxville, TN in 2015 and 2016. The error bars represent two SES of mean.

Table 4. Overall total soluble solid (TSS) of 'Cinnamon Girl' pumpkin fruit assessed at harvest and every 2 weeks until 8 weeks postharvest by mulch treatments at Mount Vernon, WA and Knoxville, TN in 2015 and 2016 (locations combined).

\begin{tabular}{lcc}
\hline & \multicolumn{2}{c}{ TSS $\left({ }^{\circ}\right.$ Brix $)$} \\
\cline { 2 - 3 } & 2015 & 2016 \\
\hline Bare ground & 8.04 & $7.49 \mathrm{c}^{\mathrm{z}}$ \\
BioAgri & 8.15 & $7.91 \mathrm{ab}$ \\
Exp. PLA/PHA & 8.32 & $7.84 \mathrm{abc}$ \\
Naturecycle & 8.00 & $7.97 \mathrm{ab}$ \\
Organix & 8.11 & $7.94 \mathrm{ab}$ \\
Polyethylene & 8.07 & $8.14 \mathrm{a}$ \\
WeedGuardPlus & 8.21 & $7.78 \mathrm{bc}$ \\
$P$-value & 0.54 & 0.02 \\
\hline
\end{tabular}

${ }^{\mathrm{z}}$ Treatment means compared using Fisher's least significant difference test at $\alpha=0.05$. Treatment means followed by the same letter within a column are not significantly different.

${ }^{\mathrm{y}}$ Experimental film made with polylactic acid (PLA)/polyhydroxyalkanoate (PHA) polymers.

the season ( $\leq 7 \%$ at Mount Vernon and $\leq 25 \%$ at Knoxville) compared with 2015, where PSE in some plots reached $63 \%$ and $100 \%$ by the end of the season at Mount Vernon and Knoxville, respectively. Knoxville had higher average air and soil temperature $\left(7.5\right.$ and $\approx 5{ }^{\circ} \mathrm{C}$ higher, respectively) compared with Mount Vernon. Other studies have found that BDM deterioration increases with increased solar radiation, temperature, rainfall, and humidity (Kijchavengkul et al., 2008; Miles et al., 2012).

There were essentially no weeds in any of the mulch treatments at Mount Vernon and very few weeds at Knoxville in both years because mulches remained sufficiently intact cucumber (Cucumis sativus) from soil warming due to dark-colored paper and plastic BDMs compared with bare ground or lighter colored paper. However, at Knoxville, total pumpkin yield did not differ because of mulch treatments, where the average soil temperature was higher than at Mount Vernon, and was similar among all mulch treatments. These results suggest that mulching may not increase crop yield during the summer in warmer regions provided that there is satisfactory weed control. The overall average pumpkin yield was higher at Mount Vernon in 2015 compared with 2016, and likely was because of higher solar radiation ( $9 \%$ higher), air temperature $\left(1{ }^{\circ} \mathrm{C}\right.$ higher), and soil temperature $\left(1.8^{\circ} \mathrm{C}\right.$ higher $)$ in 2015 than in 2016. At Knoxville, the overall average pumpkin yield was lower in 2015 than in 2016, because strong spring storms with heavy rains, wind, and hail not long after planting slowed plant growth initially in 2015. In addition, Knoxville had higher air temperature $\left(1{ }^{\circ} \mathrm{C}\right.$ higher $)$ and soil temperature $\left(1.8^{\circ} \mathrm{C}\right.$ higher $)$ in 2016 than in 2015 . Miles et al. (2012) reported that increased soil temperature under the mulch treatment appeared to favor tomato yield. Many other studies have reported crop yield to be similar for plastic BDMs and PE mulch, e.g., lettuce (Lactuca sativa) (Brault et al., 2002), melon (Filippi et al., 2011; Iapichino et al., 2014; Shogren and Hochmuth, 2004), tomato (Cirujeda et al., 2012a; Cowan et al., 2014; Martin-Closas et al., 2008; Moreno and Moreno, 2008), and cucumber (Wortman et al., 2016).

Lower TSS in fruit grown on bare ground than in plastic mulched beds at both locations in 2016 was likely because of the environmental differences noted previously. Although, it is also possible that low TSS in fruit grown on bare ground was because of less plant vigor, and lower nutrient and water uptake, but these measurements were not taken in this study. Cowan et al. (2014) also found higher TSS in tomato fruit grown on $\mathrm{PE}$ and BDMs compared with bare ground. This result suggests that mulches can improve fruit TSS compared with bare ground. We observed that mulch fragments tended to continue to adhere on fruit over the 8 weeks of storage. There was no difference in the storage quality because of mulch treatment, but TSS was not measured specifically for fruit with mulch adhesion.

Pumpkin marketable yield was reduced at Mount Vernon both years because of adhesion of BDM (except Exp. PLA/PHA) on fruit at places where the fruit rested on the mulch during the growing season. By contrast, mulch adhesion was relatively low at Knoxville because most of the pumpkin fruit set was outside the mulched bed because of longer vine growth. Observations at both locations indicated that adhered mulch could be wiped off fruit in the early morning, when fruit were damp from morning dew; however, as the temperature increased, and the mulch dried on the fruit, the mulch became more difficult to remove. Adhesion of BDM can be an important issue for crops such as pumpkin 
or watermelon where fruit rest on the mulch surface and remain in direct contact during the growing season. Labor cost increases when adhered mulch must be cleaned from the fruit, and marketable yield decreases if these fruit have to be discarded because of quality concerns. Also, mulch adhesion on fruit increases the risk of plastics entering the food processing stream and impairing the quality and food safety of the products and byproducts. The main outcomes from the current study indicate that total yield and quality of pumpkin grown with BDMs are comparable to PE mulch, however, fruit that rest for prolonged times on BDM may have mulch adhesion that can reduce marketable yield, and paper mulch can prevent nutsedge penetration.

\section{Literature Cited}

AgWeatherNet. 2016. Washington State Univ. AgWeatherNet, Mount Vernon, WA. 6 Jan. 2016. <http://weather.wsu.edu/>.

Anzalone, A., A. Cirujeda, J. Aibar, G. Pardo, and C. Zaragoza. 2010. Effect of biodegradable mulch materials on weed control in processing tomatoes. Weed Technol. 24:369-377.

Arguez, A., I. Durre, S. Applequist, M. Squires, R. Vose, X. Yin, and R. Bilotta. 2010. NOAA's U.S. climate normals (1981-2010). Knoxville experimental station, TN US GHCND: USC00404946. NOAA National Centers for Environmental Information. 29 June 2016. $<$ https://www.ncdc.noaa.gov/>.

Brault, D., K.A. Stewart, and S. Jenni. 2002. Growth, development, and yield of head lettuce cultivated on paper and polyethylene mulch. HortScience 37:92-94.

Cirujeda, A., J. Aibar, A. Anzalone, L. MartínClosas, R. Meco, M.M. Moreno, A. Pardo, A.M. Pelacho, F. Rojo, A. Royo-Esnal, M.L. Suso, and C. Zaragoza. 2012a. Biodegradable mulch instead of polyethylene for weed control of processing tomato production. Agron. Sustain. Dev. 32:889-897.

Cirujeda, A., A. Anzalone, J. Aibar, M.M. Moreno, and C. Zaragoza. 2012b. Purple nutsedge (Cyperus rotundus L.) control with paper mulch in processing tomato. Crop Prot. 39:66-71.

Cowan, J.S., C.A. Miles, P.K. Andrews, and D.A. Inglis. 2014. Biodegradable mulch performed comparably to polyethylene in high tunnel tomato (Solanum lycopersicum L.) production. J. Sci. Food Agr. 94:1854-1864.

Emmert, E.M. 1957. Black polyethylene for mulching vegetables. Proc. Amer. Soc. Hort. Sci. 69:464-469.

Filippi, F., G. Magnani, S. Guerrini, and F. Ranghino. 2011. Agronomic evaluation of green biodegradable mulch on melon crop. Ital. J. Agron. 6:111-116.
Galinato, S.P., C. Miles, and S. Ponnaluru. 2012. Cost estimates of producing fresh market field-grown tomato in western Washington. Washington State Univ. Ext. Publ. FS080E, Washington State Univ., Pullman, WA.

Galinato, S.P. and T.W. Walters. 2012. Cost estimates of producing strawberries in a high tunnel in western Washington. Washington State Univ. Ext. Publ. FS093E.

Grossman, E. 2015. How can agriculture solve its $\$ 5.87$ billion plastic problem? GreenBiz. 20 Mar. 2016. <https://www.greenbiz.com/article/ how-can-agriculture-solve-its-1-billion-plasticproblem>.

Haapala, T., P. Palonen, A. Korpela, and J. Ahokas. 2014. Feasibility of paper mulches in crop production-A review. Agr. Food Sci. 23:6079.

Haapala, T., P. Palonen, A. Tamminen, and J. Ahokas. 2015. Effects of different paper mulches on soil temperature and yield of cucumber in the temperate zone. Agr. Food Sci. 24:52-58.

Hayes, D., L. Wadsworth, H. Sintim, M. Flury, M. English, S. Schaeffer, and A. Saxton. 2017. Effect of diverse weathering conditions on the physicochemical properties of biodegradable plastic mulches. Polym. Test. 62:454-467.

Iapichino, G., G. Mustazza, L. Sabatino, and F. D'Anna. 2014. Polyethylene and biodegradable starch-based mulching films positively affect winter melon production in Sicily. Acta Hort. 1015:225-231.

Ibarra-Jimenez, L., R. Quezada-Martin, B. CedenoRubalcava, A.J. Lozano, D. Rio, and M. de la Rosa-Ibarra. 2006. Watermelon response to plastic mulch and row covers. Eur. J. Hort. Sci. 71:262-266.

Kasirajan, S. and M. Ngouajio. 2012. Polyethylene and biodegradable mulches for agricultural applications: A review. Agron. Sustain. Dev. 32:501-529.

Kijchavengkul, T., R. Auras, M. Rubino, M. Ngouajio, and R.T. Fernandez. 2008. Assessment of aliphatic-aromatic copolyester biodegradable mulch films. Part I: Field study. Chemosphere 71:942-953.

Lamont, W. 2005. Plastics: Modifying the microclimate for the production of vegetable crops. HortTechnology 15:477-481.

Levitan, L. and A. Barros. 2003. Recycling agricultural plastics in New York State. Environmental Risk Analysis Program. Cornell Univ., Ithaca, NY. 19 Mar. 2016. <http://cwmi.css. cornell.edu/recyclingagplastics.pdf $>$.

Li, C., J. Moore-Kucera, C. Miles, K. Leonas, J. Lee, A. Corbin, and D. Inglis. 2014. Degradation of potentially biodegradable plastic mulch films at three diverse U.S. locations. Agroecol. Sustain. Food Syst. 38:861-889.

Limpus, S. 2012. Comparison of biodegradable mulch products to polyethylene in irrigated vegetable, tomato and melon crops. Final re- port MT09068. Queensland Dept. Agr. Fisheries For., Queensland, Australia.

Liu, E.K., W.Q. He, and C.R. Yan. 2014. 'White revolution' to 'white pollution'-Agricultural plastic film mulch in China. Environ. Res. Lett. 9:091001.

MarketsandMarkets. 2012. Agricultural films market by applications and polymers-Global trends and forecasts to 2017. MarketsandMarkets Research Private Ltd., Maharashtra, India.

Martin-Closas, L., M.A. Bach, and A.M. Pelacho. 2008. Biodegradable mulching in an organic tomato production system. In: R.K. Prange and S.D. Bishop (eds.). XXVII IHC-S11 Sustain. through Integr. and Org. Hort. Acta Hort. 767:267-274

Merfield, C. 2000. Organic weed management: A practical guide. 10 Oct. 2016. <https:// researcharchive.lincoln.ac.nz/handle/ 10182/4902>.

Miles, C., R. Wallace, J. Cowan, and D.A. Inglis. 2012. Deterioration of potentially biodegradable alternatives to black plastic mulch in three tomato production regions. HortScience 47:1270-1277.

Minuto, G., L. Pisi, F. Tinivella, C. Bruzzone, S. Guerrini, M. Versari, S. Pini, and M. Capurro. 2008. Weed control with biodegradable mulch in vegetable crops. Acta Hort. 801:291-297.

Moreno, M.M. and A. Moreno. 2008. Effect of different biodegradable and polyethylene mulches on soil properties and production in a tomato crop. Scientia Hort. 116:256-263.

Rangarajan, A. and B. Ingall. 2006. Biodegradable mulch product testing 2006. Cornell Univ., Ithaca, NY. 26 Dec. 2016. <http://www.vegetables. cornell.edu/alt/Biodegradable\%20Mulch\%20Product $\% 20$ Testing\%2020063.pdf $>$.

Saxton, A.M. 2010. DandA.sas: Design and analysis macro collection version 1.29. Univ. Tennessee, Knoxville, TN.

Schonbeck, M. 2015. Weed management strategies for organic cucurbit crops in the southern United States. 5 July 2017. <http://articles.extension. org/pages/60198/weed-management-strategiesfor-organic-cucurbit-crops-in-the-southern-unitedstates>.

Shogren, R.L. and R.C. Hochmuth. 2004. Field evaluation of watermelon grown on paperpolymerized vegetable oil mulches. HortScience 39:1588-1591.

Waterer, D. 2010. Evaluation of biodegradable mulches for production of warm-season vegetable crops. Can. J. Plant Sci. 90:737-743.

Weaver, S.E. and C.S. Tan. 1983. Critical period of weed interference in transplanted tomatoes (Lycopersicon esculentum): Growth analysis. Weed Sci. 31:476-481.

Wortman, S.E., I. Kadoma, and M.D. Crandall. 2016. Biodegradable plastic and fabric mulch performance in field and high tunnel cucumber production. HortTechnology 26:148-155. 